\title{
Prostaglandin concentrations in the semen of hypogonadal men during treatment with testosterone
}

\author{
N. E. Skakkebaek,* R. W. Kelly and C. S. Corker \\ M.R.C. Unit of Reproductive Biology, 2 Forrest Road, Edinburgh EH1 2QW, U.K. and \\ *The Fertility Clinic, University Department of Obstetrics and Gynaecology, \\ Rigshospitalet, Copenhagen, Denmark
}

\begin{abstract}
Although it has been known for more than 40 years that human semen contains prostaglandins, only recently have 19-hydroxyprostaglandin E-1 and E-2 (19-OH PGEs) been identified as the major prostaglandins in the semen of normal, fertile men (Taylor \& Kelly, 1974; Jonsson, Middleditch \& Desiderio, 1975). Nothing is known about the control of synthesis and release of these compounds, although there is evidence that the smooth muscle-stimulating activity of human semen, which is attributed to prostaglandins, is androgen dependent (Sturde, 1968). To investigate the role of androgens in the production of 19-OH PGEs, we have measured prostaglandin concentrations in repeated semen samples from two hypogonadal men before and during treatment with testosterone.

Patient 1 was unmarried, aged 26 years; he suffered from a lack of pubertal development caused by an isolated gonadotrophin deficiency. He had previously been treated with 3000 i.u. HCG (Physex: LEO Laboratories, Denmark) twice weekly for approximately 1 year; 150 i.u. HMG (Humantex: LEO Laboratories, Denmark) had also been given twice weekly during the last 3 months of this period. The combined treatment initiated normal pubertal changes, the patient was able to achieve satisfactory orgasm and ejaculation, and spermatozoa were present in the ejaculate. After puberty, the gonadotrophin therapy was replaced by treatment with testosterone suppositories (D.A.K., Denmark), 20 or $40 \mathrm{mg}$ daily. The patient had been on this testosterone treatment for approximately 6 months before the present study began. Peripheral blood testosterone levels were in the normal range for adult men during the HCG-HMG and the testosterone treatments, but feil to within the normal range for females when treatment was stopped.

Patient 2 was married and 36 years old when examined. The right testis was congenitally absent and 6 years before the study began the left testis had been removed because of a seminoma. By 6 months after the operation libido was lost and ejaculation was impossible. The peripheral testosterone levels were far below the normal range and exploratory surgery confirmed that there was no testicular tissue. Approximately 8 months before the present study began, the patient was treated with testosterone suppositories, $40 \mathrm{mg}$ twice daily; libido returned to normal, and the first ejaculation occurred a few days after treatment had begun.
\end{abstract}

\section{Methods}

Patient 1 took part in two studies. Experiment 1 was of short duration and was preceded by a 5 day period during which $40+20 \mathrm{mg}$ testosterone were administered daily. For the next 7 days no testosterone was given. Twice daily doses of $20 \mathrm{mg}$ each were then initiated. Nine semen samples were obtained throughout this period (Text-fig. 1a). Experiment 2 lasted for 54 days and included an initial period during which $20 \mathrm{mg}$ testosterone were administered twice daily. A period of 10 days when no testosterone was given was followed by four 10-day treatment periods in which increasing doses of testosterone were given (Text-fig. 1b). The two semen samples required for each of the five last periods were obtained at 2 and about 10 days after every change of dose. The period of abstinence before each ejaculation was $2-3$ days.

Patient 2 participated in only one study, the protocol of which was similar to that in Exp. 2 described above (Text-fig. 1c). 


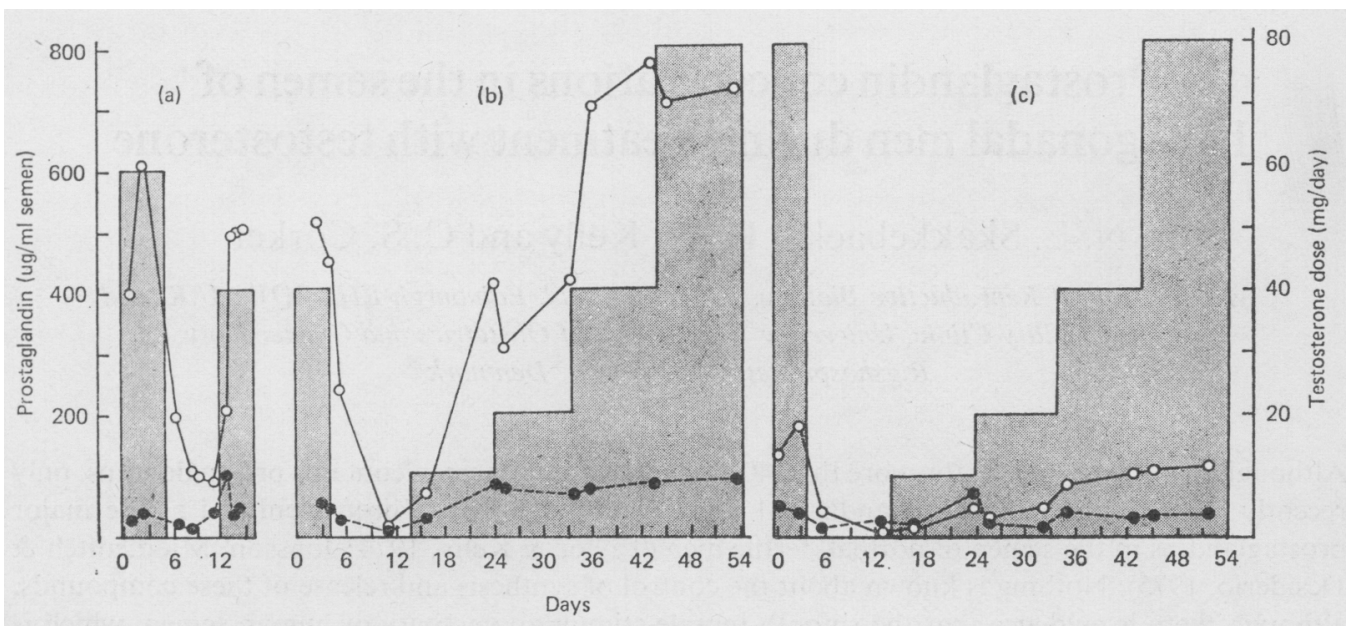

Text-fig. 1. The variation of prostaglandin concentration in the semen of two patients treated with testosterone suppositories: (a) and (b) Patient 1 ; (c) Patient 2. Shaded areas represent testosterone doses administered; O represents 19-OH PGE levels; 0 represents PGE levels.

Repeated blood samples from the antecubital vein were taken from both patients $4 \mathrm{hr}$ after insertion of a testosterone suppository. After clotting the blood was centrifuged and serum was kept frozen at $-20^{\circ} \mathrm{C}$ until assayed. Testosterone was measured by the radioimmunoassay described by Corker \& Davidson (1976). Serum concentrations of testosterone mirrored the therapeutic regimen closely. When no testosterone was given the serum testosterone varied little and was about $72 \mathrm{ng} / 100 \mathrm{ml}$. Doses of $5-10 \mathrm{mg}$ testosterone twice daily resulted in elevated serum testosterone values, although they were below the normal range for males of this age $(300-900 \mathrm{ng} / 100 \mathrm{ml})$. Doses of $20-40 \mathrm{mg}$ twice daily generally produced serum testosterone levels within the normal range.

All semen samples from Patient 1 were produced by masturbation, while those from Patient 2 were obtained after intercourse using a condom. After measuring the volume, the whole semen was transferred to a tube containing acetone and kept at $-20^{\circ} \mathrm{C}$ until analysed. Prostaglandins E-1 and E-2 and 19-OH PGEs in the semen were measured by the gas chromatographic method of Cooper \& Kelly (1975).

\section{Results and discussion}

Both patients were able to ejaculate throughout the experiments, although the composition of the seminal fluid was markedly altered by the dose of testosterone. As expected, there was a gradual fall in the total volume of semen following the withdrawal of testosterone treatment in both patients. In Patient 1 the mean volume during testosterone administration was $2.8 \mathrm{ml}$ (range 1.4-4.9 ml) and this fell to $2.1 \mathrm{ml}$ (range $1.0-3.3 \mathrm{ml}$ ) when no testosterone was given. The values for Patient 2 were $1.1 \mathrm{ml}$ (range $0.2-1.5 \mathrm{ml}$ ) and $0.7 \mathrm{ml}$ (range $0.3-1.0 \mathrm{ml}$ ). Of the prostaglandins measured, the most pronounced and consistent influence was on the concentration of 19-OH PGEs which fell to $<20 \%$ of the treatment values within 1-3 days of withdrawal of testosterone therapy (Text-fig. 1). The concentration of PGEs in semen was less affected and though changes were observed, none of the correlations between the dose of testosterone and seminal PGE concentrations was significant. There was however a significant correlation between the dose of testosterone and the concentration of 19-OH PGEs in semen (Patient 1: $r=0.88, P<0.001$; Patient 2: $r=0.92, P<0.001$ ).

This study clearly shows that the changes in the concentrations of seminal 19-OH PGEs are related to the blood testosterone levels.

The role of prostaglandins in human semen remains controversial. Many authors suggest that prostaglandins may play a role in the transport of spermatozoa in the female genital tract (Kurzrok 
\& Lieb, 1930-31; Goldblatt, 1933; von Euler, 1934; Cockrill, Miller \& Kurzrok, 1935; Asplund, 1947; Eliasson, 1959, 1966; Sandberg, Ingelman-Sundberg, Lindgren \& Ryden, 1962; Bygdeman \& Eliasson, 1963; Bygdeman, Hamberg \& Samuelsson, 1966), and some studies have shown that low PGE levels in semen are related to infertility (Hawkins \& Labrum, 1961; Sturde, 1968; Hawkins, 1968; Bygdeman, 1969). The finding that the concentration of 19-OH PGEs in semen is androgendependent makes it tempting to suggest that these compounds may also be involved in the reproductive process.

We thank Miss I. Cooper and Miss H. McLean for technical assistance, Dr S. E. Brandt and Dr P. Brandt for blood samples, and Dr R. V. Short for valuable advice. N.E.S. was supported in part by a grant from the Danish Medical Research Council.

\section{References}

Asplund, J. (1947) Some preliminary experiments in connection with the effest of prostaglandin on the uterus and tubae in vivo. Acta physiol. scand. 13, 109-114.

Bygdeman, M. (1969) Prostaglandins in human seminal fluid and their correlation to fertility. Int. J. Fert. 14, 228-231.

Bygdeman, M. \& Eliasson, R. (1963) The effect of prostaglandin from human seminal fluid on the motility of the non pregnant human uterus in vitro. Acta physiol. scand. 59, 43-51.

Bygdeman, M., HamberG, M. \& Samuelsson, B. (1966) The content of different prostaglandins in human seminal fluid and their threshold doses on the human myometrium. Mem. Soc. Endocr. 14, 49-64.

Cockrill, J.R., Miller, E.G., Jr \& Kurzrok, R. (1935) The substance in human seminal fluid affecting uterine muscle. Am.J.Physiol. 112, 577-580.

COOPER, I. \& Kelly, R.W. (1975) The measurement of E and 19-hydroxy $E$ prostaglandin in human seminal plasma. Prostaglandins 10, 507-514.

Corker, C.S. \& DAvidson, D.W. (1976) A radioimmunoassay for testosterone in various biological fluids without chromatography. J. Steroid Biochem. (in press).

Eliasson, R. (1959) Studies on prostaglandin. Occurrence, formation and biological actions. Acta physiol. scand. 46, Suppl. 158.

Eliasson, R. (1966) The effect of different prostaglandins on the motility of the human myometrium. Mem. Soc. Endocr. 14, 77-88.
Goldblatt, M.W. (1933) A depressor substance in seminal fluid. J. Soc. Chem. Indust. 52, 1056-1057.

HAWKINS, D.F. (1968) Relevance of prostaglandins to problems of human subfertility. In Prostaglandin Symp., Worcester Fndn exp. Biol. pp. 1-10. Eds P. W. Ramwell \& J. E. Shaw. Interscience, New York.

Hawkins, D.F. \& Labrum, A.H. (1961) Semen prostaglandin levels in fifty patients attending a fertility clinic. J. Reprod, Fert. 2, 1-10.

Jonsson, H.T., Middledirch, B.S. \& Desiderio, D.M. (1975) Prostaglandins in human seminal fluid: two novel compounds. Science, N. Y. 187, 1093-1094.

KurzroK, R. \& Lieb, C.C. (1930-31) Biochemical actions of human semen. II. The actions of semen on the human uterus. Proc. Soc. exp. Biol. Med. 28, 268-272.

Sandberg, F., Ingelman-Sundberg, A., Lindgren, L. \& RYDEN, G. (1962) In vitro effects of prostaglandin on different parts of the human Fallopian tube. Nature, Lond. 193, 78 I-782.

STURDE, H.-C. (1968) Experimentelle Untersuchungen zur Frage der Prostaglandine und ikvir Beziehungen zur mannlichen Fertilitat. Arzneim. Forsch. 18, 895-900, 1158-1163, 1298-1310.

TAYLOR, P.L. \& KeLLY, R.W. (1974) 19-Hydroxylated E prostaglandins as the major prostaglandins of human semen. Nature, Lond. 250, 665-667.

VON EULER, U.S. (1934) Zur Kenntnis der pharmakologschen Wiskungen von Nativsekreten und Extrakten mannlichen accessorischen Geschlechtsdrusen. Arch. Path. Pharmac. 175, 78-87. 